\title{
Miconazole と䯣液持続排液が有効であった
}

\author{
クリプトコックス髄膜炎の 1 治験例
}

\begin{tabular}{llll} 
& & \multicolumn{2}{c}{ 豊橋市民病院脳神経外科 } \\
福井 一裕 岡村 & 和彦 渡辺 正男 \\
中村 茂俊 山本 昌幸 & &
\end{tabular}

（昭和63年11月 7 日受付）

(昭和63年12月13日受付)

Key words : Cryptococcal meningitis, Miconazole, CSF drainage

要旨

クリプトコックス髄膜炎は人の深在性真菌症の中では最も頻度が高く, 種々の免疫不全状態の患者に 発症することが多いが，本例のような健常人での発症の報告は少ない．また抗真菌剤として Amphotericin B (AMPH-B) や5-fluorocytosine (5-FC) に加えて Miconazole が臨床使用され, 優れた安全性と 有効性が報告されている。

症例は68歳の健康な男性で, 昭和62年 3 月より頭痛, 嘔吐に加光複視と歩行障害も加わってきたため 3 月 15 日に当科入院となった。髄液検査にて多数の C. neoformans と著明な頭蓋内圧え進をみたため, 䯣液持続ドレナージを行い AMPH-B と5-FC の投与を開始した。しかし症状の改善みられず，これらの 薬物による副作用が出現した。そこで, Miconazole の静注と䯣注に治療変更した所, 髄液所見, 臨床所 見とも改善し，8月14日に退院した。その後昭和63年 2 月より䯣液真菌数の再上昇を示したため, 3 月 10日より4月30日まで再入院にて Miconazole を投与し軽快した. Miconazole の総投与量は初回入院時 $90.6 \mathrm{~g}$ (髄腔内投与 : $505 \mathrm{mg}$ ), 次回入院時 $36.0 \mathrm{~g}$ （髄腔内投与： $50 \mathrm{mg}$ ）であったが副作用は示さなかっ た。 また, 初回入院時の長期の髄液持続ドレナージにより頭蓋内圧元進を抑制した点も患者の救命上重 要であった。

\section{はじめに}

クリプトコックス髄膜炎はCryptococcus neoformans に上る難治性の真菌性髄膜炎の一つで あり死亡率も高く Amphotericin-B (AMPH-B) や5-fluorocytosine (5-FC) の出現によりその生存 率が向上してきたもののそれらの薬物の強い副作 用のために投与の減量, 投与期間の短縮拈よび中 止せざるを学ない場合が多い。今回我々は基礎疾 患なく発症した一次性のクリプトコックス髄膜炎 に対し, 腰椎クモ膜下腔にドレナージチューブを 乗入して髄液の持続的ドレナージを行いつつ, Miconazole（フロリード注 ${ }^{\circledR}$ ) の投与にて治癒し

別刷請求先 (T440) 豊橋市松葉町 3-1

豊橋市民病院脳神経外科福井一裕
た症例を経験したので報告する。

\section{症例}

患者：68歳, 男, 別荘管理.

主訴：頭痛, 嘔吐, 複視, 歩行障害.

現病歴：患者は以前より周囲にハトが多く生息 する山間の別荘で，枯れ葉掃除などの仕事をし， ハトの糞に暴露される環境にいた。昭和 62 年 3 月 はじめょり頭痛, 嘔吐と食欲不振が進行し, 近医 にて感冒薬処方されていたが改善せず，3 月10日 頃より複視と歩行障害が出現してきたため 3 月 15 日当科入院となった。

既往歴：昭和59年左滲出性中耳炎.

家族歴：特記すべきことなし。

入院時現症：身長 $155 \mathrm{~cm}$ ，体重 $60 \mathrm{~kg}$ ，体温 36.0 
Table 1 Laboratory Findings

\begin{tabular}{|c|c|c|}
\hline \multicolumn{2}{|c|}{ Hematological Findings } & $1.0 \mathrm{mg} / \mathrm{dl}$ \\
\hline $\mathrm{Hb}$ & $15.8 \mathrm{~g} / \mathrm{dl}$ & $134 \mathrm{mEq} / \mathrm{l}$ \\
\hline WBC & $12100 / \mathrm{mm}^{3}$ & $3.1 \mathrm{mEq} / l$ \\
\hline N-stab. & $1 \%$ & $99 \mathrm{mEq} / \mathrm{l}$ \\
\hline N-seg. & $85 \%$ & Serological findings \\
\hline $\mathrm{E}$ & $0 \%$ & ASO \\
\hline B & $0 \%$ & CRP \\
\hline M & $7 \%$ & $1064 \mathrm{mg} / \mathrm{dl}$ \\
\hline Lym & $7 \%$ & $438 \mathrm{mg} / \mathrm{dl}$ \\
\hline Thr. & 22.3 万 $/ \mathrm{mm}^{3}$ & $110 \mathrm{mg} / \mathrm{dl}$ \\
\hline Urinalysis & & Immunological findings \\
\hline Protein & $30 \mathrm{mg} / \mathrm{dl}$ & T-cell $\quad 75 \%(60 \sim 89 \%)$ \\
\hline Glucose & $(-)$ & $7 \%(4 \sim 13 \%)$ \\
\hline $\begin{array}{l}\text { Keton } \\
\text { occult blor }\end{array}$ & $\begin{array}{l}(-) \\
(-)\end{array}$ & $\begin{array}{c}28877 \mathrm{CPM} \\
(37700 \sim 62400)\end{array}$ \\
\hline ESR & $7 \mathrm{~mm} / \mathrm{hr}$ & CON-A $\quad 23600 \mathrm{CPM}$ \\
\hline \multicolumn{2}{|c|}{ Blood chemistry } & $(24300 \sim 58200)$ \\
\hline T.P. & $6.9 \mathrm{~g} / \mathrm{dl}$ & Serum Cryptococcal \\
\hline Al. & $61.3 \%$ & antigen $\times 1024<$ \\
\hline$\alpha_{1}$ & $3.4 \%$ & CSF findings \\
\hline$\alpha_{2}$ & $11.6 \%$ & $600 \mathrm{mmH}_{2} \mathrm{O}$ \\
\hline$\beta$ & $9.2 \%$ & Cell counts \\
\hline$\gamma$ & $14.5 \%$ & poly. \\
\hline GOT & $5 \mathrm{mU} / \mathrm{ml}$ & Lym. $32 / 3 / \mathrm{mm}^{3}$ \\
\hline GPT & $5 \mathrm{mU} / \mathrm{ml}$ & Protein $\quad 71 \mathrm{mg} / \mathrm{dl}$ \\
\hline ALP & $149 \mathrm{mU} / \mathrm{ml}$ & $37 \mathrm{mg} / \mathrm{dl}$ \\
\hline $\mathrm{LDH}$ & $156 \mathrm{mU} / \mathrm{ml}$ & \multirow{3}{*}{$\begin{array}{l}\text { C. neoformans } \mathrm{H} \\
\text { (India ink stain) }\end{array}$} \\
\hline T-Bil. & $0.8 \mathrm{mg} / \mathrm{dl}$ & \\
\hline BUN & $16 \mathrm{mg} / \mathrm{dl}$ & \\
\hline
\end{tabular}

${ }^{\circ} \mathrm{C}$, 脈拍 $60 /$ 分整, 血圧 $130 / 80 \mathrm{mmHg}$, 神経学的に は意識清明で瞳孔両側正円同大, 対光反射両側正 常，運動之知覚機能正常であったが著明な項部硬 直と両側眼底らっ血乳頭，複視，を見た。胸腹部 理学的所見は異常なかった。

入院時検查成績 (Table 1)：好中球主体の白血 球増加と CRP 陽性を示し, 炎症反応がみられた。 䯣液検查では䯣液圧 $600 \mathrm{mmH}_{2} \mathrm{O}$ と上昇し, 蛋白 值の上昇, 糖値の低下, リンパ球主体の細胞増多 をみた。墨汁染色にてC. neoformans が多数及 られた (Fig. 1). 咯痰, 血液, 尿の培養では C. neoformans は検出されなかった。頭部 CT では， 両側脳室の拡大をみたが，真菌性肉芽腫などはみ られず胸部 X 線も病原巣となるべき病変はみら れなかった。 また, 血清免疫学的検查にて PHA と CON-A によるリンパ球幼若化能が軽度低下して いたが，臨床的に免疫下全を強く疑う所見とは言
Fig. 1 C. neoformans from CSF (India ink stain $\times 400$ )

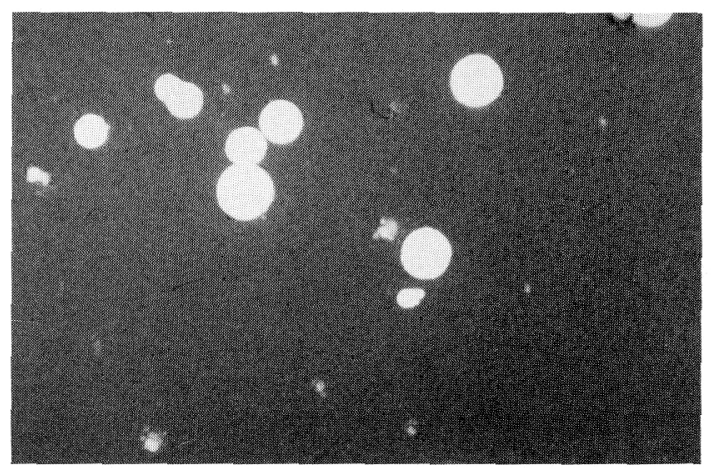

完なかった。血清クリプトコックス抗原值は1,024 倍以上の強陽性であった。

入院後経過 (Fig. 2)：以上の結果より, 健常人 に発生したクリプトコックス髄膜炎之診断し, AMPH-B の静注と5-FCの経口投与を開始した。 屯た, 患者は入院二日目より著明な頭蓋内圧六進 により意識混濁をきたしたため，腰椎穿刺による 髄液の持続的ドレナージを開始した。そして意識 レベルの改善を見たが，1週間後より AMPH-B の副作用と思われる血尿を又, 食欲低下と髄膜刺 激症状の増悪をきたし, 全身状態は著しく悪化し た。そこで, 治療開始後10日目でAMPH-B 孛中止 乙Miconazoleの静注を200mg/日から $800 \mathrm{mg} /$ 日 と増量し隔日に $20 \mathrm{mg}$ の髄注を開始した。京た患 者は経口摂取不能であったため中心静脈栄養を開 始した。4月になっても髄液中には $200 / \mathrm{mm}^{3}$ と依 然多数の真菌を認め, 5 月初には幻覚などの精神 症状や脳底髄膜炎による視力低下，聴力低下をみ た。しかし Miconazole の治療を続けるにつれそ れらも改善し, 7 月初めには髄液中真菌数は0 - 31 $\mathrm{mm}^{3}$ と著明に改善した。そして 7 月末には軽度の 聴力障害と神経因性の排尿障害を示すほかは日常 生活に不自由しない程まで改善したため，8月24 日退院した。しかし昭和 63 年 2 月 10 日, 䯣膜炎症 状は無いものの髄液中の C. neoformans 数が17/ $\mathrm{mm}^{3}$ と増加を示したため 3 月 10 日再入院して Miconazole の静注 $800 \mathrm{mg} /$ 日を 4 月10日禾で行 い, 髄液真菌数 $1 / 3 \mathrm{~mm}^{3}$ と低下したため 4 月 30 日 
Fig. 2 Clinical course of first admission

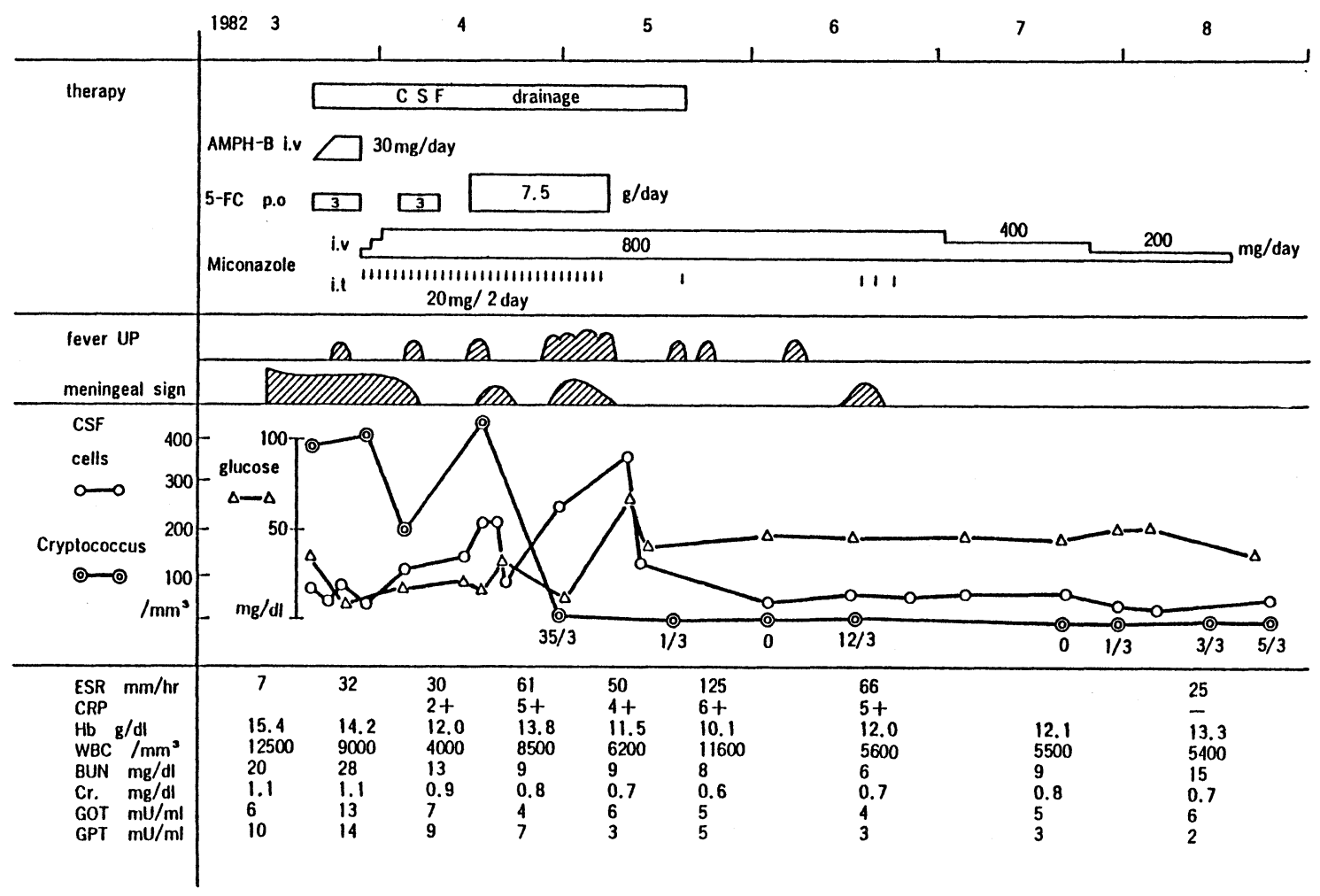

退院した. 以後外来通院しているが髄膜炎の再発 はみていない。なお，患者は初回入院の191日間に $90.6 \mathrm{~g}$ (らち髄腔内投与 $505 \mathrm{mg}$ ), 次回入院の 41 日 間に $36.0 \mathrm{~g}$ (らち髄腔内投与 $50 \mathrm{mg}$ ) の Miconazole を投与されたが副作用は示さなかった。

\section{考察}

クリプトコックス髄膜炎は, Cryptococcus neoformans によるもので，人の真菌性髄膜炎の中で は最も頻度が高く全深在性真菌症の約 $30 \%$ 占め ている ${ }^{122)}$. しかも近年, 広域抗生剂の長期連用, 免疫抑制剂, 抗腫瘍剂, 抗白血病剤の進歩による 重症疾患患者の長期延命にともなら合併症として の発症や, 白血病, 悪性リンパ腫, 糖尿病, 膠原 病などの免疫能の低下した患者での発症が注目さ れてきた。渡辺ら゙がまとめた1961年から1971年 までの127例では43.3\%に基礎疾患を有していた が，それ以降1987年までに散見される文献によれ ば13)，60\%から70\%が基礎疾患を有しての二次的 感染であり，健常人での一次感染の報告例は少な
い. しかし, 本例は健常人がハトの粪より感染し たと思われるクリプトュックス髄膜炎であった。 しかも患者は異常な頭蓋内圧方進, 髄液中クリプ トコックス菌数の異常高値, 䯣液糖值の低下, 血 中クリプトコックス抗原の異常高値などを示し, 本症の中でも予後不良といえる状態であっ $た^{334)}$.

本症は死亡率の高い疾患であったが，1956年に AMPH-B が開発され臨床使用されると死亡率 13 24\% と飛躍的に改善され，50\%から $80 \%$ の治 癒率を示している(12)5)6). 更に経口摄取できる5-FC が開発され，AMPH-B との併用療法により治癒 率は75\%から85\%と改善されてきた ${ }^{133)}$.5-FCで は耐性菌が発生し易く78), 単独治癒例の報告は少 ない.さらに1969年にイミダジール系の Miconazole が開発され，第三の抗真菌剤として深在性 真菌症に対し良好な治療効果の報告がされてき た。池本ら ${ }^{11}$ の報告では AMPH-B や5-FC に抵抗 性であった症例も含めたクリプトコックス髄膜炎 
に対し $75 \%$ の治癒率を示している. 次に以上 3 剂 の副作用発現率を文献上より比較してみると, AMPH-B 単独では63\%, AMPH-B と5-FCの併 用では $45 \%$ から56\%であるのに対し, Miconazole では約20\%と低かった ${ }^{13) 99}$ 。しかも AMPH-Bで は腎不全，尿毒症などの腎障害が約50\%に，5-FC では白血球，血小板減少などの血液毒性が約 $20 \%$ から30\%, 肝機能低下が約 $2 \%$ そられ, 時にこ れらは致命的となりらる ${ }^{13)}$. そのため投与期間を 短くしたり投与量を制限するなどの注意深い使用 が必要である。しかし Miconazole の副作用とし ては約 $20 \%$ に悪心, 嘔吐等の消化器症状, 約 $3 \%$ にGOT, GPT 上昇等が報告されているが，いず れも致命的副作用とはなっていない1)99.我々は初 回入院時, $\mathrm{BUN}$ 上昇と血尿により $\mathrm{AMPH}-\mathrm{B}$ を 中止し，5-FC の副作用と思われる悪心，嘔吐のた めに経口摂取困難となり中心静脈栄養を行った。 しかし患者は Miconazoleを初回入院の191日間 に $90.6 \mathrm{~g}$ (らち髄腔内投与 $505 \mathrm{mg}$ ), 次回入院の 41 日間に $36.0 \mathrm{~g}$ (らち髄腔内投与 $50 \mathrm{mg}$ ) 投与された が副作用は示さなかった。 クリプトコックス髄膜 炎をはじめとする深在性真菌症は治療期間が長く 大量の抗真菌剤を投与することが多いが, Miconazole は AMPH-B に比べ抗真菌力が劣ることな く安全性が高いという点で優れた薬剤であると思 う。しかし, 本剤は静注での髄液内移行には不良 であり ${ }^{10) ~ 13)}$, 真菌性髄膜炎に対しては䯣腔内投与 を併用する必要がある。そのため, 穿頭術により Ommaya recervoir を頭皮下にうめこみ，そこよ り Miconazole を側脳室内に投与して良好な治癒 を得た報告がある12) 14). また, 腰椎穿刺により持 続的に髄液を排出して, 抗真菌剤をクモ膜下腔に 注入して良好な治癒を得た報告もある ${ }^{15)}$. 我々も 著明な頭蓋内圧方進を示す髄膜炎に対しては䯣液 持続ドレナージにより治療を行うことが多く, 本 例においても有効であった。

池本らの統計では 8 例のクリプトコックス髄膜 炎に対し Miconazole を平均投与期間70日, 平均 総投与量 $83 \mathrm{~g}$ で治療したところ, 真菌消失率は $62 \%$ であり臨床効果は $75 \%$ \% 良好であったと報告 している11. これは髄液真菌数が消失しなくとも
臨床効果の改善の見られる例も存在する事を示し ている. 本例も髄液真菌数の完全な消失を見な かったが臨床的に日常生活可能なまでの改善を見 たため退院に踏み切った。 その後, 髄液真菌数の 軽度上昇を見たが，髄膜炎による自他覚症状は全 く無く, Miconazole の再投与の後, 髄液所見は改 善した。 以後髄膜炎の再発は示していない.

本例はクリプトコックス䯣膜炎の中でも基礎疾 患を持たず，血中，尿中，咯痰中にもC. neoformans が検出されなかった点も良好な治癒を得た 要因の一つと言えるが4), 急性期に拈ける髄液持 続ドレナージにより危険な頭蓋内圧え進をコント ロールした点が患者の救命上重要であり, AMPHB と5-FC が副作用のために使用できなかったク リプトコックス髄膜炎に対し, Miconazole が優 れた抗真菌力を示した 1 例としてここに報告し た。

文 献 ルの深在性真菌症に対する臨床試験成績. Jap. J. Antibio., 37(4) : 615-661, 1984.

2) 渡辺一功, 池本秀雄: 本邦の Cryptococcus 髄膜 炎. Jap. J. Med Mycol, 14 : 143-148, 1973.

3) Dismukes, W.E., Cloud, G., Gallis, H.A., et al . : Treatment of cryptococcal meningitis with combination amphotericin B and flucytosine for four as compared with six weeks. N. Eng. J. Med., 317 : 334-341, 1987.

4) Diamond, R.D. \& Bennett, J.E.: Prognostic factors in cryptococcal meningitis. Ann. Intern. Med., 80: 176-181, 1974.

5) Wytt, C.N., Dickson, P.L. \& Holt, G.W. : Cryptococcal meningitis. J. Neurol. Sciences., 53 : 283-292, 1982.

6) Butler, W.T., Alling, D.A., Spickard, A. \& Utz, J.P. : Diagnostic and prognostic value of clinical and laboratory findings in cryptococcal meningitis. N. Eng. J. Med., 270 : 59-67, 1964.

7) Utz, J.P.: Flucytosine. N. Eng. J. Med., 286: 777-778, 1972.

8) Holt, R.J.: Clinical problem with 5Fluorocytosine. Mycosen., 21(11): 363-369, 1978.

9）永井譲一, 矢部博樹, 吉田輝夫, 中山志郎：血液 悪性疾患患者に併発した重症真菌感染症に対する Miconazole の治療効果. Jap. J. Antibio., 37(3) : 303-308. 
10) ANA Espinel-Ingroff, Shadomy, S. \& Fisher, J. F.: Bioassay for miconazole. Antimicrob. Agents. Chemother., 11: 365-368, 1977.

11) Sung, J.P., Campbell, G.D. \& Grendahl, J.D., : Miconazole therapy for fungal meningitis. Arch. Neurol., 35 : 443-447, 1978.

12) Hoeprich, P.D. \& Goldstein, E.: Miconazole therapy for coccidioidomycosis. J.A.M.A., 230 : 1153-1157, 1974.

13) Graybill, J.R. \& Levine, H.B.: Successful treatment of cryptococcal meningitis with intraventricular miconazole. Arch. Intern. Med., 138: 814-816, 1978.

14）那須 繁, 福岡義輔, 熊谷幸雄, 岡村精一, 他 : Miconazole の脳室内投与により軽快せしめたク リプトコッカス髄膜炎の 1 例。感染症学雑誌, 56 : 1230-1235, 1982.

15）伊藤 章, 進藤邦彦, 加藤 進, 戸田有亮：5Fluorocytosine とアンフォテリシンーBによるク リプトコッカス髄膜炎の 1 治瘾例。内科, 35(5) : 883-888, 1975.

A Case of Cryptococcal Meningitis Successfully Treated with Miconazole and CSF Drainage

\author{
Kazuhiro FUKUI, Kazuhiko OKAMURA, Masao WATANABE, \\ Shigetishi NAKAMURA \& Masayuki YAMAMOTO \\ Department of Neurosurgery, Toyohashi Municipal Hospital
}

Cryptococcal meningitis is the most frequent fungal infection of the central nervous system, known readily to complicate with immuno-compromised patients. There are only a few cases of primary infection in healthy non-immuno-compromised patietns. Amphotericin-B (AMPH-B) and 5Fluorocytosine (5-FC) are effective agents against Cryptococcal meningitis, although, their toxicity and drug resistance are limiting factors. However, in recent years Micronazole has been widely used against fungal infections and it's effectiveness has been reported.

This is a 68 y.o. male who was admitted to Toyohashi Municipal Hospital on March 15, 1987 because of headache, vomiting, diplopia and gait disturbance. Continuous lumbar drainage was performed since lumbar puncture revealed surprisingly high cerebrospinal fluid (CSF) pressure and presence of many Cryptococcus neoformans, i.v. AMPH-B and p.o. 5-FC was also administrated. A 7 day course of i.v. AMPH-B and p.o. 5-FC showed no improvement with side effects of macroheaturia and anorexa. Then Miconazole was administrated i.v. and intrathecal (i.t.). The clinical signs and CSF laboratory data improved after a 90 day course of Miconazole therapy and the patient was discharged on August 24. But the patient was readmitted from March 10 to April 30, 1988, because of a slight increase of C. neoformans in CSF $\left(17 / \mathrm{mm}^{3}\right)$ and improved by i.v. and i.t. Micronazole. The total Miconazole dosage was $90.6 \mathrm{~g}$ (i.t.: $505 \mathrm{mg}$ ) at the first admission and $36 \mathrm{~g}$ (i.t.: $50 \mathrm{mg}$ ) at the second admission, but no side effect was seen. The reduction of elevated CSF pressure with continuous CSF drainage was also important for the treatment of such cases with increased intracranial pressure. 